\title{
Malignant Penile Neoplasm
}

National Cancer Institute

\section{Source}

National Cancer Institute. Malignant Penile Neoplasm. NCI Thesaurus. Code C7547.

A primary or metastatic malignant neoplasm that affects the penis. Representative examples include penile carcinoma and penile sarcoma. 